\title{
Biochemical and Morphologic Aspects of Peroxisomes in the Human Rectal Mucosa: Diagnosis of Zellweger Syndrome Simplified by Rectal Biopsy
}

\author{
NOBUYUKI SHIMOZAWA, YASUYUKI SUZUKI, TADAO ORII, SADAKI YOKOTA, AND \\ TAKASHI HASHIMOTO \\ Department of Pediatrics, Gifu University School of Medicine, Gifu [N.S., Y.S.,T.O.]; Department of Anatomy, \\ Yamanashi Medical School, Yamanashi [S.Y.]; Department of Biochemistry, Shinshu University School of \\ Medicine, Matsumoto [T.H.], Japan
}

\begin{abstract}
Rectal mucosa biopsy specimens from five controls and three infants with Zellweger syndrome were investigated morphologically and biochemically to elucidate peroxisomal structure and functions in the human rectal mucosa and to develop a simple method for an early postnatal diagnosis of peroxisomal deficiency disorders. After the alkaline 3,3'-diaminobenzidine reaction, peroxisomes of the rectal mucosa from the controls could be identified, electron microscopically, but not light microscopically. However, they were strongly stained using an immunoenzyme technique applied to semi-thin Epon sections and then were clearly visible under the light microscope. However, no positive granules were observed in the specimens of infants with Zellweger syndrome, using either of the two staining techniques. On immunoblot analysis, immunoreactive proteins of peroxisomal acyl-CoA oxidase and 3-ketoacyl-CoA thiolase were present in rectal mucosae from the controls; however, these enzyme proteins were not detected in tissues from the patients. Activity of dihydroxyacetone phosphate acyltransferase was detectable in rectal mucosae from the controls, whereas in those from infants with Zellweger syndrome, the activity of this enzyme was greatly reduced. These observations indicate that the peroxisomal structure and multiple functions are present in the rectal mucosa and that rectal biopsy is of potential value for the early and less invasive detection of Zellweger syndrome and other peroxisomal disorders. ( $\mathrm{Pe}$ diatr Res 24: 723-727, 1988)
\end{abstract}

\section{Abbreviations}

ZS, Zellweger syndrome

DHAP-AT, dihydroxyacetone phosphate acyltransferase

DAB, 3,3'-diaminobenzidine

BSA, bovine serum albumin

HRP, horseradish peroxidase

LM, light microscope

SDS, sodium dodecyl sulfate

PAGE, polyacrylamide gel electrophoresis

Received June 24, 1988; accepted August 10, 1988.

Correspondence Nobuyuki Shimozawa, M.D., Department of Pediatrics, Gifu University School of Medicine, 40 Tsukasa, Gifu 500, Japan.

Supported in part by Grants in Aid for Scientific Research [61304046, 61440044, and Special Project Research Grant 60127010 (inborn errors of metabolism)] from the Ministry of Education, Science and Culture, and by a Research Grant for the study of Intractable Diseases and an investigation of psychosomatic disorders from the Ministry of Health and Welfare, and Grant (62-6) from the National Center of Neurology and Psychiatry (NCNP) of the Ministry of Health and Welfare, Japan.
Recent studies revealed a new group of genetic diseases that have a number of metabolic disturbances considered to be due to peroxisomal defects, including ZS (McKusick 21410) (1), neonatal adrenoleukodystrophy (McKusick 20237) (2) and infantile Refsum disease (3). The diagnosis of these peroxisomal diseases is usually made by a combination of analysis of these metabolic errors, including very long-chain fatty acids, plasmalogen, bile acids, pipecolic acid, phytanic acid, and demonstration of the absence of peroxisomes (4).

The morphologic study of peroxisomes in mammalian tissues is limited to hepatocytes and renal tubules, because this organelle, although being ubiquitous in mammalian cells (5), is particularly large and abundant in both tissues, in comparison with others $(6,7)$. However, liver or renal biopsies in the early postnatal period are invasive. However, biopsy specimens of the rectal mucosa can be readily obtained by a simple and noninvasive technique with the use of Watson's intestinal biopsy capsule. Using this method, we investigated the presence of immunocytochemically recognizable peroxisomes and enzyme proteins of peroxisomal $\beta$-oxidation (8): acyl-CoA oxidase (EC 1.3.99.3), a bifunctional protein that exhibits the activities of enoyl-CoA hydratase (EC 4.2.1.17), and 3-hydroxyacyl-CoA dehydrogenase (EC 1.11.1.6), and 3-ketoacyl-CoA thiolase (EC 2.3.1.16) [9] by the immunoblotting method and exhibits enzyme activity of DHAP-AT (EC 2.3.1.42), a membrane-bound peroxisomal enzyme involved in the first step in the biosynthesis of etherphospholipids (10).

We used this noninvasive biochemical and morphologic approach for the early postnatal diagnosis of patients with ZS, demonstrating the absence of peroxisomes and the defects in peroxisomal $\beta$-oxidation enzymes and DHAP-AT.

\section{MATERIALS AND METHODS}

Five control patients with conditions not associated with known peroxisomal disorders and three infants with ZS (patients 1, 2, and 3) (11) were investigated. All ZS infants were Japanese and manifested typical findings and a clinical course of this syndrome. The ratio of hexacosanoic acid (C26:0)/docosanoic acid (C22:0) in serum sphingomyelin was unusually high. Three peroxisomal $\beta$-oxidation enzyme proteins were absent in liver tissues from patients 1 and 2 , and in both patients, liver peroxisomes were absent electron microscopically. Patient 3 was diagnosed by clinical and biochemical findings but a morphologic study was not performed.

Rectal biopsy. Specimens from the rectal mucosa were taken using Watson's intestinal biopsy capsule (Ferraris Development 
and Engineering Co. Ltd., London, U.K.). The capsule was placed about $5 \mathrm{~cm}$ inside the anus. The size of these specimens was about 2 to $3 \mathrm{~mm}$ in diameter and $2 \mathrm{~mm}$ thick. One of a few specimens thus obtained from the patients and controls was immediately fixed in $0.1 \%$ glutaraldehyde, $4 \%$ paraformaldehyde, $0.2 \mathrm{M}$ cacodylate buffer, $\mathrm{pH} 7.4$, at $4^{\circ} \mathrm{C}$ for use in electron microscopy, and the remaining tissues frozen and stored at $-80^{\circ} \mathrm{C}$ until the use for biochemical analysis.

Alkaline $D A B$ reaction and immunocytochemistry of catalase. The fixed specimens at rectal biopsy were refixed in $1 \%$ glutaraldehyde in $0.1 \mathrm{M}$ cacodylate buffer, $\mathrm{pH} 7.4$, for $1 \mathrm{~h}$ at $4^{\circ} \mathrm{C}$ and divided into two groups; the specimens of group 1 were incubated in alkaline $\mathrm{DAB}$ medium consisting of $2 \mathrm{mg} / \mathrm{ml}$ diaminobenzidine, $0.02 \% \mathrm{H}_{2} \mathrm{O}_{2}$, and $0.1 \mathrm{M}$ Teorell-Steuhagen buffer, $\mathrm{pH}$ 9.3, for $2 \mathrm{~h}$ at room temperature, postosmicated, and embedded in Epon (12). The specimens of group 2 were dehydrated and embedded in Epon without postosmication.

Semi-thin sections of group 2 were stained using an immunoenzyme technique as previously described (13). Briefly, the sections were treated with $10 \% \mathrm{NaOH}$ in absolute ethanol for 1 $\mathrm{h}$ at $30^{\circ} \mathrm{C}$ to remove the epoxy resin. After a 5 min-incubation with BSA $(5 \mathrm{mg} / \mathrm{ml})$, the sections were incubated with anticatalase $\operatorname{IgG}(20 \mu \mathrm{g} / \mathrm{ml})$ for $1 \mathrm{~h}$, followed by a $30-\mathrm{min}$ incubation with HRP-conjugated $\mathrm{Fab}^{\prime}$ of goat anti-rabbit IgG. HRP activity was visualized by the DAB reaction (14). The sections were airdried and mounted with Entellan (Merck, Darmstadt, Germany) and examined using a Nikon LM. For the immunocytochemical control, the sections were incubated with an IgG fraction from a nonimmunized rabbit, followed by the HRP-conjugated Fab'. Some sections were incubated directly with the HRP-Fab' without the preceding step of the specific antibody.

Immunoblotting. The specimens of rectal mucosa were homogenized with 5 vol of $50 \mathrm{mM}$ potassium phosphate buffer (pH 8 ) and $0.5 \%$ Triton X-100. The supernatant obtained by centrifugation $(12,000 \mathrm{rpm}, 5 \mathrm{~min})$ at $4^{\circ} \mathrm{C}$ was taken up in the same volume of sample buffer $(125 \mathrm{mM}$ Tris- $\mathrm{HCl}, \mathrm{pH} 7.4,5 \%$ SDS, $0.32 \mathrm{M}$ 2-mercaptoethanol, $20 \%$ glycerol, and $0.0025 \%$ bromophenol blue) and boiled for $3 \mathrm{~min}$. These extracts, containing $30 \mu \mathrm{g}$ of proteins, were applied to SDS/PAGE, then Western blotting was performed as described (15). Acyl-CoA oxidase, peroxisomal 3-ketoacyl-CoA thiolase, and catalase were located on the membrane as follows. The membrane was first blocked with $3 \%$ BSA followed by incubation with antibody against each of these enzymes, then incubated with goat antirabbit IgG alkaline phosphatase conjugate (Promega Biotec, Madison, WI). Color development was performed with the use of 5-bromo-4-chloro-3-indolyl phosphate. Purified rat enzymes and antibodies were prepared as described $(16,17)$. Catalase was purified from human erythrocytes.

Measurement of DHAP-AT activity. DHAP-AT activity was measured by the method of Schutgens et al. (18) with slight modifications. The specimens of rectal mucosa were homogenized in $5 \mathrm{mM}$ Tris- $\mathrm{HCl}$, pH $7.5,50 \mathrm{mM} \mathrm{NaCl}$ to give a protein concentration of approximately $2 \mathrm{mg} / \mathrm{ml}$. [U- $\left.{ }^{14} \mathrm{C}\right] \mathrm{DHAP}$ was generated from $\left[\mathrm{U}_{-}{ }^{14} \mathrm{C}\right]$ glycerol 3-phosphate (Amersham, Buckinghamshire, U.K.). The activity of DHAP-AT in the rectal mucosa was assayed by incubation of $20-40 \mu \mathrm{g}$ homogenate at $37^{\circ} \mathrm{C}$ for $2 \mathrm{~h}$ in $75 \mathrm{mM}$ sodium acetate buffer, $\mathrm{pH} 5.4,8 \mathrm{mM}$ $\mathrm{NaF}, 8 \mathrm{mM} \mathrm{MgCl}, 0.8 \mathrm{mg} \mathrm{BSA}, 0.3 \mathrm{mM}$ palmytoyl-CoA and $0.1 \mathrm{mM}$ DHAP in a total volume of $0.12 \mathrm{ml}$. Radioactivity incorporated into the chloroform-soluble lipid was determined.

\section{RESULTS}

Staining of peroxisomes by alkaline $D A B$ and immunoenzyme techniques. In the specimens from controls, peroxisomes of rectal mucosa were stained positively by the alkaline DAB reaction (Fig. $1 A$ ), whereas in those from $\mathrm{ZS}$ infants, no positive granules were observed (Fig. $1 B$ ). With LM, it was difficult to identify these small peroxisomes in the materials stained by the alkaline
DAB technique (data not shown). When the semi-thin Epon sections were stained using the immunoenzyme technique after the removal of epoxy resin, discrete granular reaction deposits were noted in epithelial cells of the controls (Fig. $2 A$ ), but not in those from the ZS infants (Fig. $2 B$ ). In the immunocytochemical control sections, no granular staining was observed.

Immunoblot analysis. Acyl-CoA oxidase consists of three components of different sizes: component $\mathrm{A}(\mathrm{Mr}=72000), \mathrm{B}(\mathrm{Mr}=$ $52000)$, and $\mathrm{C}(\mathrm{Mr}=21000)$. All three components were detected in both liver and rectal mucosae from the controls, yet only the component $\mathrm{A}$ was detected in rectal mucosa from patients with $\mathrm{ZS}$, as in the case of liver tissue. This can be explained by the finding that component $A$ was synthesized by pulse labeling of the fibroblasts from the patients, but components $\mathrm{B}$ and $\mathrm{C}$ were not formed by processing of component A (19) (Fig. 3A).

As shown in Figure $3 B$, the human peroxisomal 3-ketoacyl$\mathrm{CoA}$ thiolase seen in controls is slightly larger than the rat enzyme. In tissues from the patients, we observed a faint band of protein that was slightly higher in mol wt than the mature enzymes of human peroxisomal 3-ketoacyl-CoA thiolase. These bands are considered to be a precursor form of the thiolase, inasmuch as the pulse-chase experiments of fibroblasts revealed that the precursor form of peroxisomal 3-ketoacyl-CoA thiolase was not processed to its mature form in such patients (19). However, catalase (Fig. $3 C$ ) was present in tissues from the patients and from the controls. Bifunctional protein, another peroxisomal $\beta$-oxidation enzyme, was present only in a minute amount in rectal mucosae even from the controls (data not shown).

$D H A P-A T$ activity. The DHAP-AT activity in the rectal mucosa from the controls was about half of that in the liver whereas in both tissues from patients, the activity of this enzyme was reduced, as compared to those of the controls. Only patient 3 seemed to have a partial activity of this enzyme, but the activity in the liver from the patient was strongly reduced as in the other two cases (Table 1).

\section{DISCUSSION}

Recent immunocytochemical studies clarified localization of the individual enzymes of peroxisomal $\beta$-oxidation in the human liver and kidney $(20,21)$. In other tissues, except for cultured skin fibroblasts, biochemical or cytochemical studies of this organelle were limited because of the small number and size of the peroxisomes.

We have now obtained evidence for not only the presence of peroxisomal functions, including proteins of $\beta$-oxidation enzymes and activities of DHAP-AT, but also immunocytochemical demonstration of this organelle in the human rectal mucosa. In the present study, we have stained the peroxisomes of rectal mucosa using two different methods: the alkaline $\mathrm{DAB}$ technique and the immunoenzyme technique applied to semi-thin Epon sections. With the former, peroxisomes could be observed electron microscopically, but not light microscopically. However, with the latter technique peroxisomes were stained strongly and light microscopical identification presented no difficulty. These results indicate that the immunoenzyme technique applied to the semi-thin Epon sections is most useful for detection of peroxisomes in specimens of the rectal biopsy.

We found that these peroxisomal structures and functions were absent in rectal mucosa from infants with ZS. Ultrastructural and cytochemical demonstration of peroxisomal defects in ZS has been noted in hepatocytes, renal proximal tubules (22), and cultured skin fibroblasts (23). In the fibroblasts, small round or slightly oval peroxisomes were seen in both control and ZS infants, although the number of peroxisomes were significantly reduced in all ZS cell lines. Deficient proteins of peroxisomal $\beta$ oxidation enzymes and activities of DHAP-AT in ZS infants have been reported, the former in the liver $(24,25)$ and in fibroblasts (26), the latter in the liver, fibroblasts (18), and 

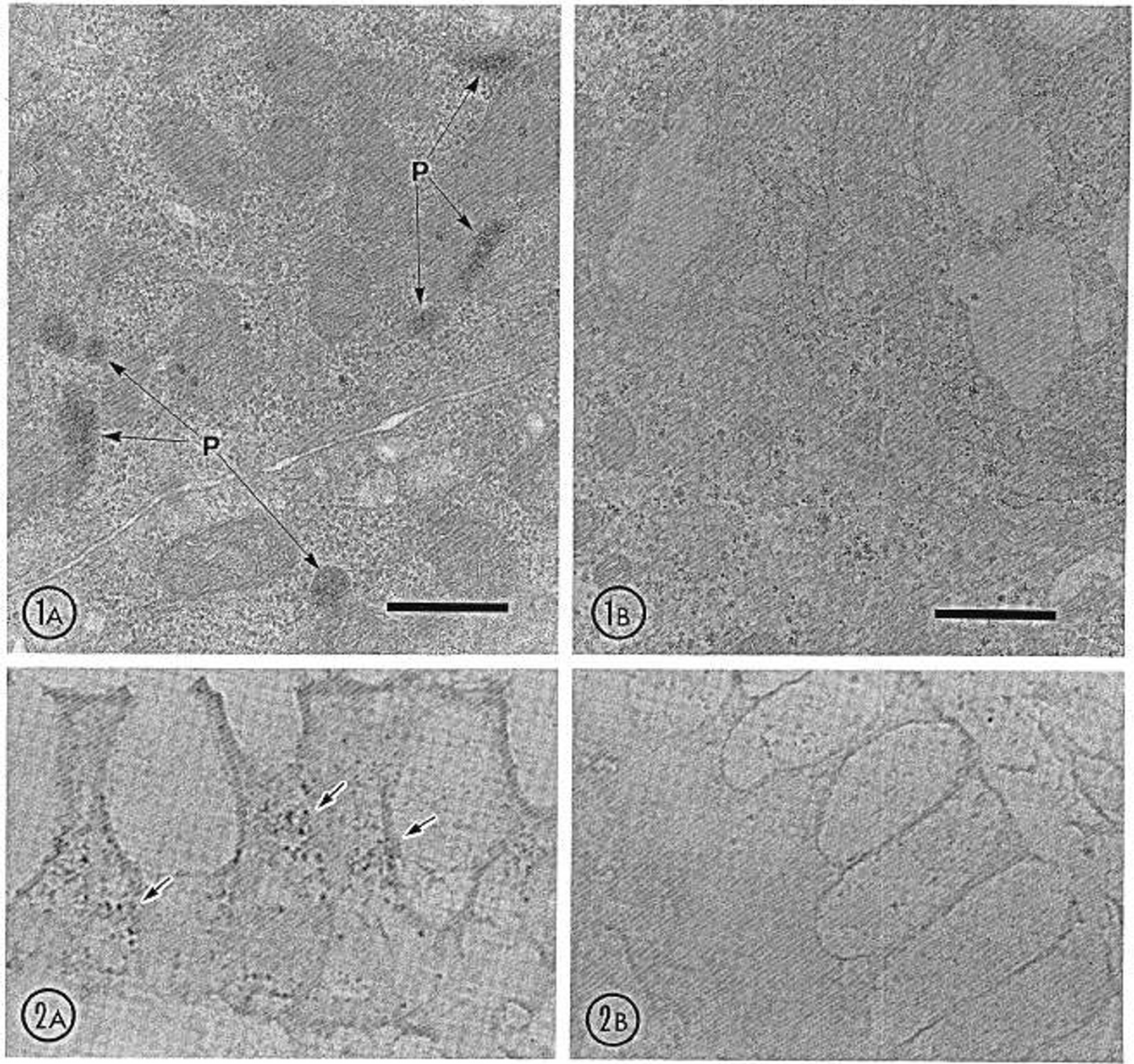

Fig. 1. Electron micrographs of mucous epithelial cells from human rectal biopsy. The cells were stained by alkaline DAB method. $A$, specimen from the control. Small peroxisomes $(P)$ were stained. Other cell organelles are negative for the reaction. $B a r=0.5 \mu \mathrm{m} . \times 36,000$. $B$, specimen from $\mathrm{ZS}$ infant. Note that there are no DAB reaction granules. Bar $=1 \mu \mathrm{m} . \times 18,000$.

Fig. 2. Light micrographs of mucous epithelial cells from human rectal biopsy. Semi-thin Epon sections of the materials were stained for catalase by immunoenzyme technique after removal of epoxy resin. $A$, specimen from the control. Small cytoplasmic granules are stained and they are crowded in some part of the cytoplasm (arrows). $\times 1400 . B$, specimen from ZS infant. Note that there are no positively stained cytoplasmic granules. $\times 1400$.

thrombocytes (27). These structural and functional defects in ZS infants have apparently never been identified in the rectal mucosa.

Rectal biopsy using Watson's intestinal biopsy capsule has been done in case of ultrastructural studies of neuronal storage disease $(28,29)$, and with this method, there are no complications such as infection, bleeding, and perforation. This method is potentially superior to the previously used methods including liver and renal biopsy with the demerits of involved techniques and invasiveness, and skin biopsy with those of time-consuming culturing of fibroblasts, as a diagnostic test for neonates with ZS. It is simple, safe, rapid, and reliable.
We consider this of potential value for diagnosis of other peroxisomal deficiency disorders with multiple dysfunction such as infantile Refsum disease $(30,31)$ and neonatal adrenoleukodystrophy $(32,33)$. Biochemical studies of peroxisomal $\beta$-oxidation and ether phospholipid in biopsied rectal mucosa will lead to an accurate diagnosis of other peroxisomal disease such as rhizomelic chondrodysplasia punctata (McKusick 21510) with a deficiency of DHAP-AT (34), pseudo-ZS with a single deficiency of peroxisomal 3-ketoacyl-CoA thiolase (35), pseudoneonatal adrenoleukodystrophy with acyl-CoA oxidase deficiency (36), and Zellweger-like syndrome with deficient proteins of peroxisomal $\beta$-oxidation enzymes and detectable peroxisomes (37). 


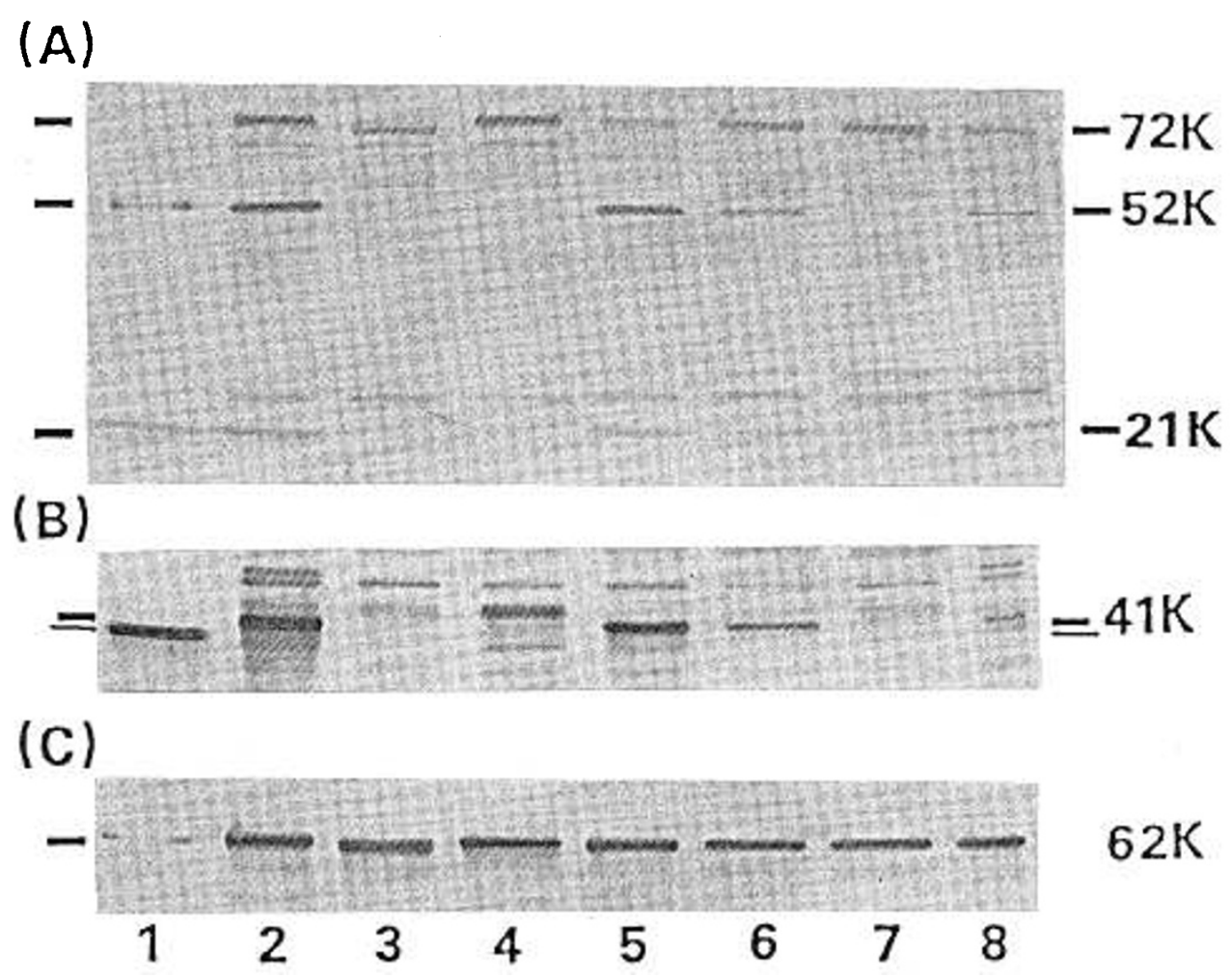

Fig. 3. Immunoblot analysis. $A$, peroxisomal acyl-CoA oxidase $(72 \mathrm{~K}$, component A; $52 \mathrm{~K}$, component $\mathrm{B}$; $21 \mathrm{~K}$, component C); $B$, peroxisomal 3 ketoacyl-CoA thiolase; $C$, catalase; lane 1: purified rat enzyme; lanes 2 and 5 : liver homogenates from the controls; lanes 3 and $4:$ liver homogenates from ZS infants; lanes 6 and 8: rectal mucosal homogenates from the controls; lane 7: rectal mucosal homogenate from ZS infant.

Table 1. DHAP-AT activity in tissues

\begin{tabular}{ccc}
\hline Tissue & Rectal Mucosa & Liver \\
\cline { 2 - 3 } & \multicolumn{2}{c}{$(\mathrm{nmol} / 2 \mathrm{~h} \mathrm{mg}$ protein) } \\
\hline Controls $(n=5)$ & $1.35 \pm 0.34$ & $2.90 \pm 0.76$ \\
& $(0.94-1.79)$ & $(2.15-4.64)$ \\
ZS & 0.06 & 0.05 \\
Patient 1 & 0.07 & 0.02 \\
Patient 2 & 0.29 & 0.05 \\
Patient 3 &
\end{tabular}

Acknowledgments. The authors thank Professor K. Hirayama, Department of Pediatrics, Ryukyu University, Okinawa and Dr. J. Shimabukuro, Department of Pediatrics, Okinawa Chubu Hospital, Gushikawa, for providing the opportunity to investigate specimens from their patients and to $\mathrm{M}$. Ohara for critical comments.

\section{REFERENCES}

1. Bowen P, Lee CSN, Zellweger H, Lindenberg R 1964 A familial syndrome of multiple congenital defects. Bull Johns Hopkins Hosp 114:402-414

2. Ulrich J, Herschkowitz N, Heitz P, Sigrist TH, Baerlocher P 1978 Adrenoleukodystrophy. Preliminary report of a connatal case. Light and electron microscopical, immunohistochemical and biochemical findings. Acta Neuropathol 43:77-83

3. Scotto JM, Hadchouel M, Odievre M, Laudat MH, Saudubray JM, Dulac O, Beucler I, Beaune P 1982 Infantile phytanic acid storage disease, a possible variant of Refsum's disease: three cases, including ultrastructural studies of the liver. J Inherited Metab Dis 5:83-90

4. Schutgens RBH, Heymans HSA, Wanders RJA, van den Bosch H, Tager JM 1986 Peroxisomal disorders: a newly recognised group of genetic diseases. Eur J Pediatr 144:430-440

5. Hruban Z, Vigil EL, Slesers A, Hopkins E 1972 Microbodies: constituent organelles of animal cells. Lab Invest 27:184-191

6. Bock P, Kramar R, Pavelska M (eds) 1980 Peroxisomes and related particles in animal tissues. Cell Biology Monographs 71. Springer, New York

7. DeDuve C 1983 Microbodies in the living cell. Sci Am 248:74-84
8. Lazarow PB, DeDuve C 1976 A fatty acyl-CoA oxidizing system in rat liver peroxisomes; enhancement by clofibrate, a hypolipidemic drug. Proc Natl Acad Sci USA 73:2043-2046

9. Hashimoto T 1982 Individual peroxisomal $\beta$-oxidation enzymes. Ann NY Acad Sci 386:5-12

10. Hajra AK, Burke CL, Jones CL 1979 Subcellular localization of acylcoenzyme A: dihydroxyacetone phosphate acyltransferase in rat liver peroxisomes (microbodies). J Biol Chem 254:10896-10900

11. Shimozawa N, Suzuki Y, Yamaguchi S, Shimizu N, Orii $\Upsilon 1988$ Peroxisomal disorders: clinical and biochemical studies. No To Hattatsu (in press)

12. LeHir M, Herzog V, Fahimi HD 1979 Cytochemical detection of catalase with $3,3^{\prime}$-diaminobenzidine. A quantitative reinvestigation of the optimal conditions. Histochemistry 54:51-66

13. Litwin JA, Yokota S, Hashimoto T, Fahimi HD 1984 Light microscopic immunocytochemical demonstration of peroxisomal enzymes in epon sections. Histochemistry $81: 15-22$

14. Graham RC, Karnovsky MJ 1966 The early stages of absorption of injected horseradish peroxidase in the proximal tubules of mouse kidney: ultrastructural cytochemistry by a new technique. J Histochem Cytochem 14:291-302

15. Towbin H, Staehelin T, Gordon J 1979 Electrophoretic transfer of protein from polyacrylamide gels to nitrocellulose sheets: procedure and some applications. Proc Natl Acad Sci USA 76:4350-4354

16. Osumi T, Hashimoto T, Ui N 1980 Acyl-CoA oxidase of rat liver: a new enzyme for fatty acid oxidation. J Biochem (Tokyo) 87:1735-1746

17. Miyazawa S, Osumi T, Hashimoto T 1980 The presence of a new 3-oxoacylCoA thiolase in rat liver peroxisomes. Eur J Biochem 103:589-596

18. Schutgens RBH, Romeijn GJ, Wanders RJA, van den Bosch H, Schrakamp G, Heymans HSA 1984 Deficiency of acyl-CoA: Dihydroxyacetone phosphate acyltransferase in patients with Zellweger (cerebro-hepato-renal) syndrome. Biochem Biophys Res Commun 120:179-184

19. Schram AW, Strijland A, Hashimoto T, Wanders RJA, van den Bosch $H$, Tager JM 1986 Biosynthesis and maturation of peroxisomal $\beta$-oxidation enzymes in fibroblasts in relation to the Zellweger syndrome and infantile Refsum disease. Proc Natl Acad Sci USA 83:6156-6158

20. Litwin JA, Volkl A, Muller-Hocker J, Hashimoto T, Fahimi HD 1987 Immunocytochemical localization of peroxisomal enzymes in human liver biopsies. Am J Pathol 128:141-150

21. Litwin JA, Volkl A, Muller-Hocker J, Fahimi HD 1988 Immunocytochemical demonstration of peroxisomal enzymes in human kidney biopsies. Virchows Archiv [Cell Pathol] 54:207-213

22. Goldfischer S, Moore CL, Johnson AB, Spiro AJ, Valsamis MP, Wisniewski HK, Ritch RH, Norton WT, Rapin I, Gartner LM 1973 Peroxisomal and mitochondrial defects in the cerebro-hepato-renal syndrome. Science 182:62-64

23. Arias JA, Moser AB, Goldfischer SL 1985 Ultrastructural and cytochemical 
demonstration of peroxisomes in cultured fibroblasts from patients with peroxisomal deficiency disorders. J Cell Biol 100:1789-1792

24. Tager JM, ten Harmsen van der Beek WA, Wanders RJA, Hashimoto T, Heymans HSA, van den Bosch H, Schutgens RBH, Schram AW 1985 Peroxisomal $\beta$-oxidation enzyme proteins in the Zellweger syndrome: Biochem Biophys Res Commun 126:1269-1275

25. Suzuki Y, Orii T, Mori M, Tatibana M, Hashimoto T 1986 Deficient activities and proteins of peroxisomal $\beta$-oxidation enzymes in infants with Zellweger syndrome. Clin Chim Acta 156:191-196

26. Shimozawa $N$, Suzuki Y, Orii $T$, Hashimoto $T 1988$ Immunoblot detection of enzyme proteins of peroxisomal $\beta$-oxidation in fibroblasts, amniocytes and chorionic villous cells: possible marker for prenatal diagnosis of Zellweger syndrome. Prenat Diagn 8:287-298

27. Wanders RJA, van Weringh G, Schrakamp G, Tager JM, van den Bosch $H$, Schutgens RBH 1985 Deficiency of acyl-CoA: dihydroxyacetone phosphate acyltransferase in thrombocytes of Zellweger patients: a simple postnatal diagnostic test. Clin Chim Acta 151:217-221

28. Ichihashi $\mathrm{H}$, Orii $\mathrm{T}$, Shoumura S, Isono H 1978 Ultrastructural study of the rectal mucosa obtained by biopsy in four cases of hereditary storage diseases. J Clin Electron Microsc 11:453-454

29. Yamano T, Shimada M, Okada S, Yutaka T, Kato T, Yabuuchi H 1982 Ultrastructural study of biopsy specimens of rectal mucosa. Its use in neuronal storage diseases. Arch Pathol Lab Med 106:673-677

30. Roels F, Cornelis A, Poll-The BT, Aubourg P, Ogier H, Scotto JM, Saudubray JM 1986 Hepatic peroxisomes are deficient in infantile Refsum disease: a cytochemical study of 4 cases. Am J Med Genet 25:257-271
31. Wanders RJA, Schutgens RBH, Schrakamp G, van den Bosch H, Tager JM, Schram AW, Hashimoto T, Poll-The BT, Saudubrau JM 1986 Infantile Refsum disease: deficiency of catalase-containing particles (peroxisomes), alkyldihydroxyacetone phosphate synthase and peroxisomal $\beta$-oxidation enzyme proteins. Eur J Pediatr 145:172-175

32. Goldfischer S, Colling J, Rapin I, Coltoff-Schiller B, Chang $\mathrm{CH}$, Nigro $\mathrm{M}$, Black VH, Javitt NB, Moser HW, Lazarow PB 1985 Peroxisomal defects in neonatal-onset and X-linked adrenoleukodystrophy. Science 227:67-70

33. Chen WW, Watkins PA, Osumi T, Hashimoto T, Moser HW 1987 Peroxisomal $\beta$-oxidation enzyme proteins in adrenoleukodystrophy: distinction between $\mathrm{X}$-linked adrenoleukodystrophy and neonatal adrenoleukodystrophy. Proc Natl Acad Sci USA 84:1425-1428

34. Heymans HSA, Oorthuys JWE, Nelck G, Wanders RJA, Dingemans KP, Schutgens RBH 1986 Peroxisomal abnormalities in rhizomelic chondrodysplasia punctata. J Inherited Metab Dis 9(suppl 2):329-331

35. Schram AW, Goldfischer S, van Roermund CWT, Brouwer-Kelder EM, Collins J, Hashimoto T, Heymans HSA, van den Bosch H, Schutgens RBH, Tager JM, Wanders RJA 1987 Human peroxisomal 3-oxoacyl-coenzyme A thiolase deficiency. Proc Natl Acad Sci USA 84:2494-2496

36. Moser AB, Moser HW, Naidu S 1987 Observations about the phenotype of peroxisomal disorders. In: Fahimi HD, Sies $\mathrm{H}$ (eds) Peroxisomes in Biology and Medicine. Springer, New York, pp 335-340

37. Suzuki Y, Shimozawa N, Orii T, Igarashi N, Kono N, Hashimoto T 1988 Molecular analysis of peroxisomal $\beta$-oxidation enzymes in infants with Zellweger syndrome and Zellweger-like syndrome: further heterogeneity of the peroxisomal disorder. Clin Chim Acta 172:65-76 